\title{
MOLECULAR ANALYSIS OF GUT BACTERIAL ENDOSYMBIONTS DIVERSITY IN RED PALM WEEVIL LARVAE, Rhynchophorus ferrugineus (COLEOPTERA; CURCULIONIDAE)
}

\author{
Osman $^{1}$, B.M.A.; M. Magdy ${ }^{2}$; S.F. Elsharabasy ${ }^{1}$; M.A. Rashed ${ }^{2}$ \\ and S.A. Ibrahim ${ }^{2}$ \\ 1- Plant Protection Dept., Central Lab. for Date Palm Researches, Agric. Research Center, \\ Giza, Egypt \\ 2- Genetics Dept., Fac. of Agric., Ain Shams Univ., Cairo, Egypt
}

Keywords: Red palm weevil, DGGE, Endosymbionts, 16S rRNA

\section{ABSTRACT}

Red palm weevil, Rhynchophorus ferrugineus (Oliver, 1790), Order; Coleoptera, Family; Curculionidae, is considered as the biggest threat facing date palm cultivators. The larva feed on trunk tender tissue and can cause palm death within 6-8 months after infection. Insect gut harbors a community of bacteria that lives in an endosymbiotic relationship with the insect and it is strongly evident that it plays a key role in insect life. Deciphering and identification of insect microbiota could lead to the development of new symbiotiontbased control approaches. In this work we studied the diversity of the endosymbiont bacterial community of red palm weevil larval midgut in Egypt, by using Denaturing Gradient Gel Electrophoresis (DGGE), based on 16S rRNA genes PCR amplification. We used three groups of field caught larva sampled from two different places; El-Badrashin and Agricultural Research Center (ARC) in Giza governorate, Egypt. DGGE profiling patterns has shown the relative prevalence of bacterial phylotypes affiliated to family Firmicute; Leuconostoc lactis, Lactococcus lactis, Lactobacillus nagelli and bacterial phylotypes affiliated to family Actinobaceria; Cellulomonas cellasea, Bifidobacterium minimum, which suggest that they have a potential role in nutrition, physiology and immunomodulation of the insect.

\section{INTRODUCTION}

Date palm (Phoenix dactylifera L.) is considered to be one of the oldest cultivable trees in the world. North Africa and The Arab peninsula are the major date palm cultivation zones, it is the primary source of income for more than 10 million people in north Africa (Zouine et al 2005). According to (FAOSTAT, 2013), Egypt ranks as the first country in dates production with 1.3 million tons / year, it has approximately 15 million bearing female palm trees distributed all over the country governorates. Egypt exports 25 thousand tons/year of dates (FAOSTAT, 2013). Dates productivity has declined over the last decade because of disease, pests and lacking of developmental researches. One of the major date palm threats is the red palm weevil (Rhynchophorus ferrugineus, Family; Curculionidae). It was originated from South-East Asia and spread increasingly with the expansion of trade and travel in the world, and became the major palm pest in the Mediterranean area (Ferry and Gomez, 2002). It was first recorded in Egypt at November 1992 in El-Sharquiya governorate and then to the rest of all the country governorates. The adult weevils attracted by the volatiles emitted from wounded palms (Kairomone) and lay their eggs in the opening wounds on the trunk. Larva is the most destructive stage, after hatching it begins to tunnel towards the interior of the palm making larger cavities while feeding on tender tissues in the trunk. Red palm weevil attack can result in palm death within 6-8 months. (Avand Faghih 1996; Murphy and Briscoe 1999; Dembilio \& Jacas 2011). 
Integrated Pest Management (IPM) aims to make use of different control methods to optimize the insect population density in the infested areas (Rajamanickam et al 1995). The red palm weevil IPM strategy mainly includes; pheromone trapping, insecticides and quarantine protocols. Using insecticide as the most effective and widely practiced treatment for infested palm trees, implicates heavy environmental impacts especially for human and non-targeting invertebrates. There is a strong requirement for developing new techniques and approaches to be applied in red palm weevil integrated pest management strategy in order to decline the role of insecticides to a very low level.

Insect gut harbors a wealth of rich communities of nonpathogenic microorganisms. A single gut could harbors $10^{5}-10^{9}$ of prokaryotic cells including; bacteria (primarily dominated), archaea, fungi, protists, viruses (Engel and Moran, 2013). It is increasingly evident that gut microbial community play an essential role in its host biology. They are not only involved in digestion and nutrition of insects, but they also could serve as protective and antimicrobial symbionts, help in recovering from abiotic and biotic stresses (Oliver et al 2010), enhance and improve the innate immune system (Hamdi et al 2011), improve sexual performance, fertility (Behar et al 2008), longevity, evolution, and insect development. Identification and exploitation of the gut microbiota could lead proposing innovative and promising solutions for insect related problems, this approach is called; Microbial Resource Management (MRM) (Verstraete et al 2007). Thus, knowing the composition of original gut microbial community of the target insect is considered as a necessary prerequisite for establishing new symbiont-based approaches.

Despite of its economic importance, there is still little information is known about red palm weevil gut microbiota. This study aims to provide exploration and analysis of the bacterial endosympionts associated to the gut of field caught R.ferrugineus larvae in Egypt, based on bacterial 16S rRNA genes. We used denaturing gradient gel electrophoresis (DGGE) technique as a cultureindependent method followed by sequencing and phylogenetic analysis to introduce a vision of the potential roles of identified gut bacterial community

\section{MATERIALS AND METHODS}

\section{Insects}

Three groups of field caught red palm weevil larvae (the destructive stage of insect) were col- lected in winter, between the two high annual peaks of the red palm weevil (October and March). The samples collected from two different places; El-Badrashin (sample A), Agriculture Research Center ARC (sample B and sample D). Each larvae group was collected from a different infested date palm which has a clear history of treatment with chemical or biological insecticides. Larvae were collected in a sterile plastic container half filled with the larval frass and trunk tender tissues from the larval tunnels (as a food). Every larval group consists of 25-22 larvae. Samples were dominated by later instars, and its weigh was between 1.7 to $4.5 \mathrm{~g}$. The temperature of the infected palm trees was measured during sampling by digital thermometer with a metal probe, beside that the temperature of the surrounding healthy date palm trees was measured at the same time. The temperature of the infested trees was $\left(31.4-32.4^{\circ} \mathrm{C}\right)$, while the temperature of the healthy trees was $\left(17.6-18.1^{\circ} \mathrm{C}\right)$, and the average temperatures of the sampling days were $\left(18.2-20.3^{\circ} \mathrm{C}\right)$.

\section{Larvae dissection}

The larvae were dissected within 24 hours from the collection time. They were washed with sterile saline $(0.9 \% \mathrm{NaCl})$, followed by surface serialization by washing several times with $70 \%$ (V/V) ethanol and were allowed to evaporate. The larvae were dissected aseptically under a laminar flow biosafety level II by using sterile micro- scissors and the whole gut lumen was hold with a fine forcipes while it was still connected with the head capsule, then the gut content was evacuated in a clean sterile $50 \mathrm{ml}$ tube with a syringe filled with sterile $0.9 \% \mathrm{NaCl}$ saline. After collecting all of gut contents in the $50 \mathrm{ml}$ propylene tube, it was stored at $-80^{\circ} \mathrm{C}$ till the metagenomic DNA extraction process.

\section{DNA extraction and PCR amplification of bacte- rial 16S rRNA genes}

DNA of the bulk microbial community was extracted by DNA purification kit (MO BIO Laboratories, 12888-50, Carlsband, CA) according to the manufacture's protocol with the modification of (Elsaied et al 2002). The PCR amplification of the bacterial 16S rRNA genes was performed by using the primers 341F-GC, 5 - CGC CCG CCG CGC GCG GCG GGC GGG GCG GGG GCA CGG GGG G CC TAC GGG AGG CAG CAG-3` and 907R, 5 - CCG TCA ATT CMT TTG AGT TT-3` 
Rhynchophorus ferrugineus (Coleoptera; Curculionidae)

(Muyzer et al 1993). Amplification was carried out in a $50 \mu \mathrm{l}$ final volume; $25 \mu \mathrm{l}$ of $2 \mathrm{X}$ MyTaq $^{\mathrm{TM}}$ Mix, $1 \mu$ of (BSA, Thermoscientific, $20 \mathrm{mg} / \mathrm{ml}), 1 \mu \mathrm{M}$ of each primer and about $5 \mathrm{ng}$ of template DNA. The PCR was performed in Thermal Cycler (ProFlex ${ }^{\mathrm{TM}}$ PCR system, Life technology, USA) by using a touch-down gradient PCR program (DeLong and Pace, 2001) as follows; initial denaturation at $95^{\circ} \mathrm{C}$ for $4 \mathrm{~min}$; 30 cycles of $94^{\circ} \mathrm{C}$ for $50 \mathrm{sec}$, annealing at $60^{\circ} \mathrm{C}\left(-0.3^{\circ} \mathrm{C}\right.$ per cycle $)$ for $50 \mathrm{sec}$, and extension at $72^{\circ} \mathrm{C}$ for $40 \mathrm{sec} ; 5$ cycles of $94^{\circ} \mathrm{C}$ for 40 $\mathrm{sec}$, annealing at $60^{\circ} \mathrm{C}$ for $40 \mathrm{sec}$, and extension at $72^{\circ} \mathrm{C}$ for $60 \mathrm{sec}$, followed by final extension $72^{\circ} \mathrm{C}$ for $12 \mathrm{~min}$. Amplicons were loaded in $1.5 \%$ agarose gel electrophoresis with $1 \mathrm{~kb}$ DNA ladder marker and visualized using ethidium bromide under UV light.

\section{Denaturing Gradient Gel Electrophoresis (DGGE)}

DGGE was performed according to (Muyzer et al 1993), using DCode ${ }^{T M}$ Mutation Detection System (Bio-Rad, UK). The PCR products Loaded in $7 \%$ acrylamide gels that contained a urea plus formamide gradient $(100 \%$ denaturing solution contains $420 \mathrm{~g} / \mathrm{L}$ urea and $40 \%$ formamide). DGGE was conducted at $120 \mathrm{~V}$ and $35 \mathrm{Amp}$ at $60^{\circ} \mathrm{C}$ for $17 \mathrm{~h}$ in $1 \times \mathrm{TAE}$ running buffer $(1 \times \mathrm{TAE}$ buffer is $0.04 \mathrm{M}$ Tris acetate, $2 \mathrm{mM}$ EDTA, $\mathrm{pH}$ 8.5). The gel was stained by ethidium bromide, visualized and photographed under UV gel documentation system; Gel Doc ${ }^{\mathrm{TM}} \mathrm{XR}^{+}$imager (Bio-Rad laboratories inc,UK)

\section{Bacterial 16S rRNA sequencing}

Dominant bands were carefully cut off under UV light by a sterile razor blade, placed in $50 \mu$ of d. $\mathrm{dH}_{2} \mathrm{O}$ at $40^{\circ} \mathrm{C}$ for $10 \mathrm{~min}$ and supernatant was used as a DNA template for the Re-PCR amplification. Re-amplification of the bacterial 16r RNA genes was performed by using the same primers $341 \mathrm{~F}$ without GC-clamp and 907R. Amplification checked by electrophoresis on 1.5 agarose gel. Amplicons were purified by using the PCR cleanup and gel extraction Kit (Cat No. NA006-0100, GeneDireX®, China). Purified samples were sent for Big Dye terminator cycle sequencing at Macrogen, Inc. South Korea.

\section{Sequence and phylogenetic analysis}

The sequences obtained from the 16S rRNA genes fragments were analyzed with nucleotidenucleotide BLAST to determine their closest matches in GeneBank database (National Center for Biotechnology Information, USA) to obtain the nearest phylogenetic neighbors (www.ncbi.nlm.nih.gov/BLAST/). Sequence alignments were performed by MAFFT version 7 (http://mafft.cbrc.jp/alignment/), and the phylogenetic tree was constructed by using neighborjoining method using MEGA7.1.0 software.

\section{RESULTS AND DISCUSSION}

Total diversity of the gut microbial community of Red Palm Weevil

The DGGE profile results have shown the presence of 26 visible (distinguishable) bands with an average number of ( 8 to 9 bands) per sample (Fig. 1), which indicate that the red pal weevil microbial community shows relatively low complexity structure (each DGGE band corresponded to a single Operational Taxonomic Unit (OTU), where the total banding pattern is reflective of a community's complexity and diversity (Muyzer et al 1993; Muyzer and Smalla, 1998). Contrasting results of other tree xylophagous coleopterans which rely on its microbial community for efficient cellulose and lignocellulose metabolism, high diversity and complexity was observed (Colman et al 2012), while low complexity and diversity were observed in the gut microbial community of the red turpentine weevil (Morales-Jiménez et al 2009). Red palm weevil larva throughout their development inhabit inside the palm trunk, feeding only on palm tissues (enclosed environment) (Murphy and Briscoe, 1999), feeding on live trees may expose the insect and its gut microbial community to the tree's physiological and immuno responses, without omission of the potential role of the red palm weevil antimicrobial activity in the selection of specific bacterial phylotypes (Byers, 1995; Mazza et al 2011). These two other factors may also contributed to shaping and limiting the microbial community structure of the insect (Morewood et al 2004 and War et al 2012). 


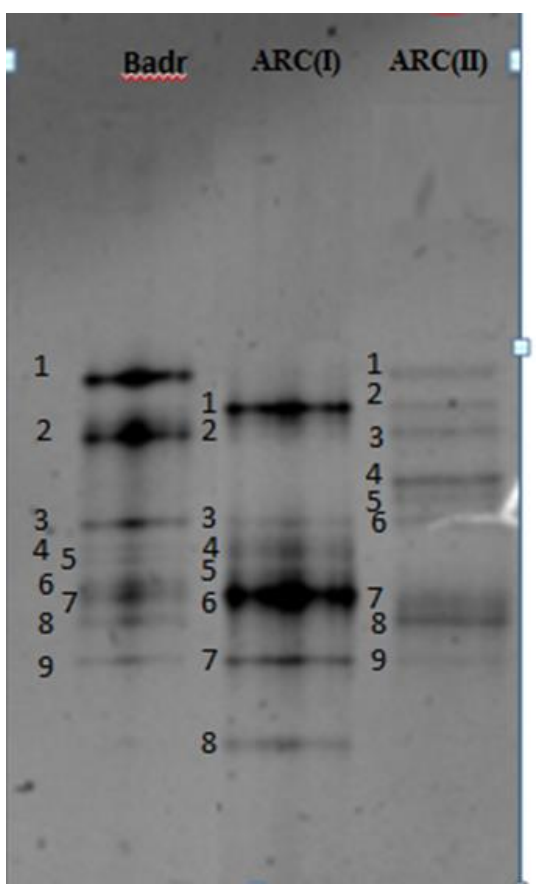

Fig. 1. DGGE profiling for PCR-amplified bacterial 16S rRNA genes fragments of the red palm weevil gut content pools. $A$ : sample $A$ from ElBadrashein), B: sample B from Agriculture Research Center (I), C: sample C from Agriculture Research Center (II)

\section{Sequence analysis and phylogenetic affiliation}

Partial sequences of the 16s rRNA genes of the gut bacterial microbiota of the red palm weevil were analyzed and sequences were compared with their most closest matches from the BLAST database search tool (Table 2) in order to detect the nearest phylogenetic neighbors. Out of 26 DGGE bands (OTUs), 17 dominant bands could be identified successfully which were represented by 7 bacterial phylotypes (Table 1). According to phylogenetic analysis (Fig. 2); DGGE-OTU 7-B.C were identified as Lactococcus lactis with identity 100\%. DGGE-OTU 2.A-C was assigned to Lactobacillus nagelii with identity 96\%. DGGE-OTU 3A.B.C was assigned to Loriellopsis cavernicola with identity $89 \%$. DGGE-OTU 1.A-C assigned to Leuconostoc lactis with $99 \%$ sequence similarity, DGGE-OTU 6.A-B-C was assigned to Cellulomonas cellasea with sequence similarity $84 \%$, DGGEOTU 4.A-B-C was assigned to Bifidobacterium minimum with sequence similatity $83 \%$, DGGEOUT 5-A.D was assigned to Pantoea wallisii with $85 \%$ sequence identity.
Table 1. DGGE bands represented by bacterial 16S rRNA genes of phylotypes which were identified in the three gut content pools of the red palm weevil

\begin{tabular}{|l|c|c|c|}
\hline \multirow{2}{*}{$\begin{array}{c}\text { Bacterial } \\
\text { Phylotypes/ } \\
\text { OTUs }\end{array}$} & \multicolumn{3}{|c|}{ DGGE bands of the gut content } \\
& \multicolumn{3}{|c|}{ pools } \\
\cline { 2 - 4 } & $\begin{array}{c}\text { EI- } \\
\text { Badrashein } \\
\text { (A) }\end{array}$ & $\begin{array}{c}\text { ARC, } \\
\text { (I) }\end{array}$ & $\begin{array}{c}\text { ARC, } \\
\text { (II) } \\
\text { (B) }\end{array}$ \\
\hline 1- A.C & $1 \mathrm{~A}$ & - & $1 \mathrm{C}$ \\
2- A.C & $2 \mathrm{~A}$ & - & $3 \mathrm{C}$ \\
3- A.B.C & $3 \mathrm{~A}$ & $3 \mathrm{~B}$ & $6 \mathrm{D}$ \\
4- A.B.C & $7 \mathrm{~A}$ & $6 \mathrm{~B}$ & $7 \mathrm{C}$ \\
5- A.D & $8 \mathrm{~A}$ & - & $8 \mathrm{D}$ \\
6- A.B.C & $9 \mathrm{~A}$ & $7 \mathrm{~B}$ & $9 \mathrm{C}$ \\
7- B.C & - & $1 \mathrm{~B}$ & $2 \mathrm{C}$ \\
\hline
\end{tabular}

Structure of red palm weevil larval gut endosymbiotic bacterial community

Out of the 26 DGGE bands (total bands numbe) are six of them are species affiliated to phylm Firmicutes which represent at least $23 \%$ of the microbial community predominant phylotypes. It was Leuconostoc lactis, Lactococcus lactis and Lactobacillus nagelli, and they are all lactic acid bacteria (LAB) (König and Fröhlich 2009). Lactic acid bacteria ( $L A B)$, are microorganisms known of their potential probiotic activity, they were reported to enhance innate immune system in bees and fruit flies, as they stimulate the transcription of genes in the immuno-responce of the insect (Evans \& Lopez, 2004 and Ryu et al 2008), in addition to that, Lactic acid bacteria are well known as producers of antimicrobial compounds, such as organic acids (lactic acid- acetic acid- formic acid- Succinic acid), hydrogen peroxide, antimicrobial polypeptides (Bacteriocisns), antibiotics, as well as several less well-defined and completely unidentified inhibitory compounds (Vandenbergh, 1993 and De Vuyst and Vandamme, 1994), They are acid tolerant bacteria which able to acidify their surrounding environment which affect the growth of pathogens that share the same gut micro-niche. Acidification caused by LAB bacteria could help in insect host protection against some microbial toxins such as Bacillus thuringiensis protoxins which need to be activated at the alkaline $\mathrm{pH}$ (Broderick et al 2003). Moreover, the bacterial fermintation activity increases the temperature in the palm tissue and may promote the insect development during the winter season. The chewed-up palm tissue (frass) fermentation result in production of some 
Molecular analysis of gut bacterial endosymbionts diversity in Red Palm Weevil larvae,

Rhynchophorus ferrugineus (Coleoptera; Curculionidae)

Table 2. Bacterial species identified in the gut of Red Palm Weevil

\begin{tabular}{|c|c|c|c|c|}
\hline $\begin{array}{c}\text { OTUs/ } \\
\text { phylotype }\end{array}$ & nt & $\begin{array}{l}\text { Closest sequence matches } \\
\text { (Accession number) }\end{array}$ & $\begin{array}{l}\text { Identity\% } \\
\text { /E value }\end{array}$ & Pylogenetic affiliation \\
\hline 1-A.C & 522 & $\begin{array}{c}\text { Leuconostoc holzapfelii BFE } \\
7000 \text { ( (NR042620.1) } \\
\text { Leuconostoc citreum ATCC } \\
49370 \text { (NR042627.1) } \\
\text { Leuconostoc lactis JCM 6123 } \\
\text { (NR113255.1) } \\
\text { Leuconostoc lactis KCTC } 3528 \\
\text { (NR040823.1) }\end{array}$ & $\begin{array}{l}(99 \%) 0.0 \\
(99 \%) 0.0 \\
(99 \%) 0.0 \\
(99 \%) 0.0\end{array}$ & $\begin{array}{l}\text { Firmicutes / Leuconostocaceae } \\
\text { Firmicutes / Leuconostocaceae } \\
\text { Firmicutes / Leuconostocaceae } \\
\text { Firmicutes / Leuconostocaceae }\end{array}$ \\
\hline 2- A.C & 290 & 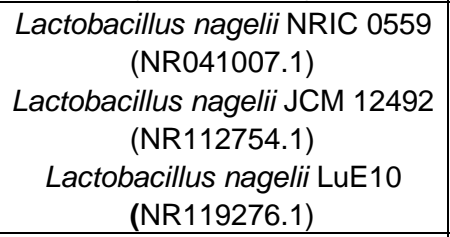 & $\begin{array}{l}(96 \%) 8 e-101 \\
(96 \%) 3 e-100 \\
(96 \%) 3 e-100\end{array}$ & $\begin{array}{l}\text { Firmicutes / Lactobacillaceae } \\
\text { Firmicutes / Lactobacillaceae } \\
\text { Firmicutes / Lactobacillaceae }\end{array}$ \\
\hline 3- A.B.C & 480 & $\begin{array}{c}\text { Cephalothrix lacustris CCIBt } \\
3261 \text { (NR137272.1) } \\
\text { Loriellopsis cavernicola LF-B5 } \\
\text { (NR117881.1) } \\
\text { Cephalothrix komarekiana CCIBt } \\
77 \text { (NR137273.1) } \\
\text { Aerosakkonema funiforme Lao26 } \\
\text { (NR114306.1) }\end{array}$ & $\begin{array}{l}8 e-128(89 \%) \\
8 e-128(89 \%) \\
4 e-126(88 \%) \\
4 e-126(88 \%)\end{array}$ & $\begin{array}{c}\text { Cyanobactria/ Oscillatoriophycideae } \\
\text { Cyanobactria/ Oscillatoriophycideae } \\
\text { Cyanobactria/ Oscillatoriaceae } \\
\text { Cyanobactria/ Oscillatoriaceae }\end{array}$ \\
\hline 4- A.B.C & 533 & 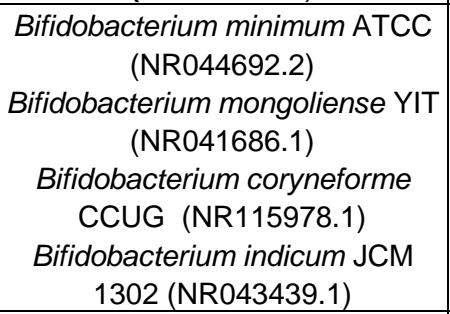 & $\begin{array}{l}(83 \%) 1 e-126 \\
(82 \%) 3 e-119 \\
(82 \%) 3 e-119 \\
(82 \%) 3 e-119\end{array}$ & $\begin{array}{l}\text { Actinobacteria/ Bifidobacteriaceae } \\
\text { Actinobacteria/ Bifidobacteriaceae } \\
\text { Actinobacteria/ Bifidobacteriaceae } \\
\text { Actinobacteria/ Bifidobacteriaceae }\end{array}$ \\
\hline 5- A.D & 440 & $\begin{array}{c}\text { Pantoea wallisii LMG } 26277 \\
\text { (NR118122.1) } \\
\text { Enterobacter cloacae ATCC } \\
13047 \text { (NR118568.1) } \\
\text { Enterobacter xiangfangensis 10- } \\
17 \text { (NR126208.1) } \\
\text { Erwinia billingiae LMG } 2613 \\
\text { (NR118431.1) }\end{array}$ & $\begin{array}{l}(85 \%) 4 e-27 \\
(85 \%) 2 e-25 \\
(85 \%) 2 e-25 \\
(85 \%) 2 e-25\end{array}$ & $\begin{array}{c}\text { Proteobacteria /Erwiniaceae } \\
\text { Proteobacteria /Enterobacteriaceae } \\
\text { Proteobacteria / Enterobacteriaceae } \\
\text { Proteobacteria /Erwiniaceae }\end{array}$ \\
\hline 6- A.B.C & 495 & 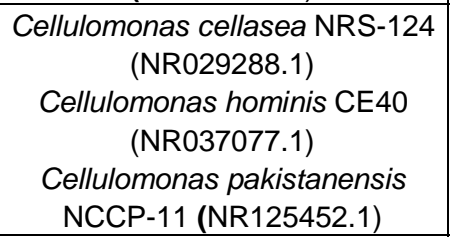 & $\begin{array}{l}(84 \%) 6 e-62 \\
(84 \%) 6 e-62 \\
(83 \%) 3 e-60\end{array}$ & $\begin{array}{l}\text { Actinobacteria/ Cellulomonadaceae } \\
\text { Actinobacteria/ Cellulomonadaceae } \\
\text { Actinobacteria/ Cellulomonadaceae }\end{array}$ \\
\hline 7- B.C & 430 & 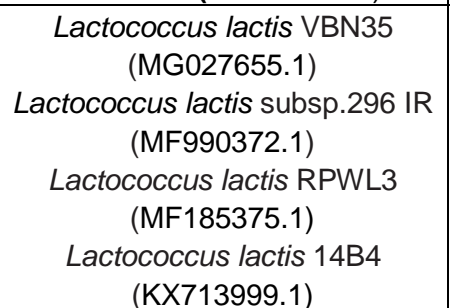 & $\begin{array}{l}(100 \%) 0.0 \\
(100 \%) 0.0 \\
(100 \%) 0.0 \\
(100 \%) 0.0\end{array}$ & $\begin{array}{l}\text { Firmicutes /Streptococcaceae } \\
\text { Firmicutes /Streptococcaceae } \\
\text { Firmicutes /Streptococcaceae } \\
\text { Firmicutes /Streptococcaceae }\end{array}$ \\
\hline
\end{tabular}

Arab Univ. J. Agric. Sci., Special Issue, 26(2A), 2018 


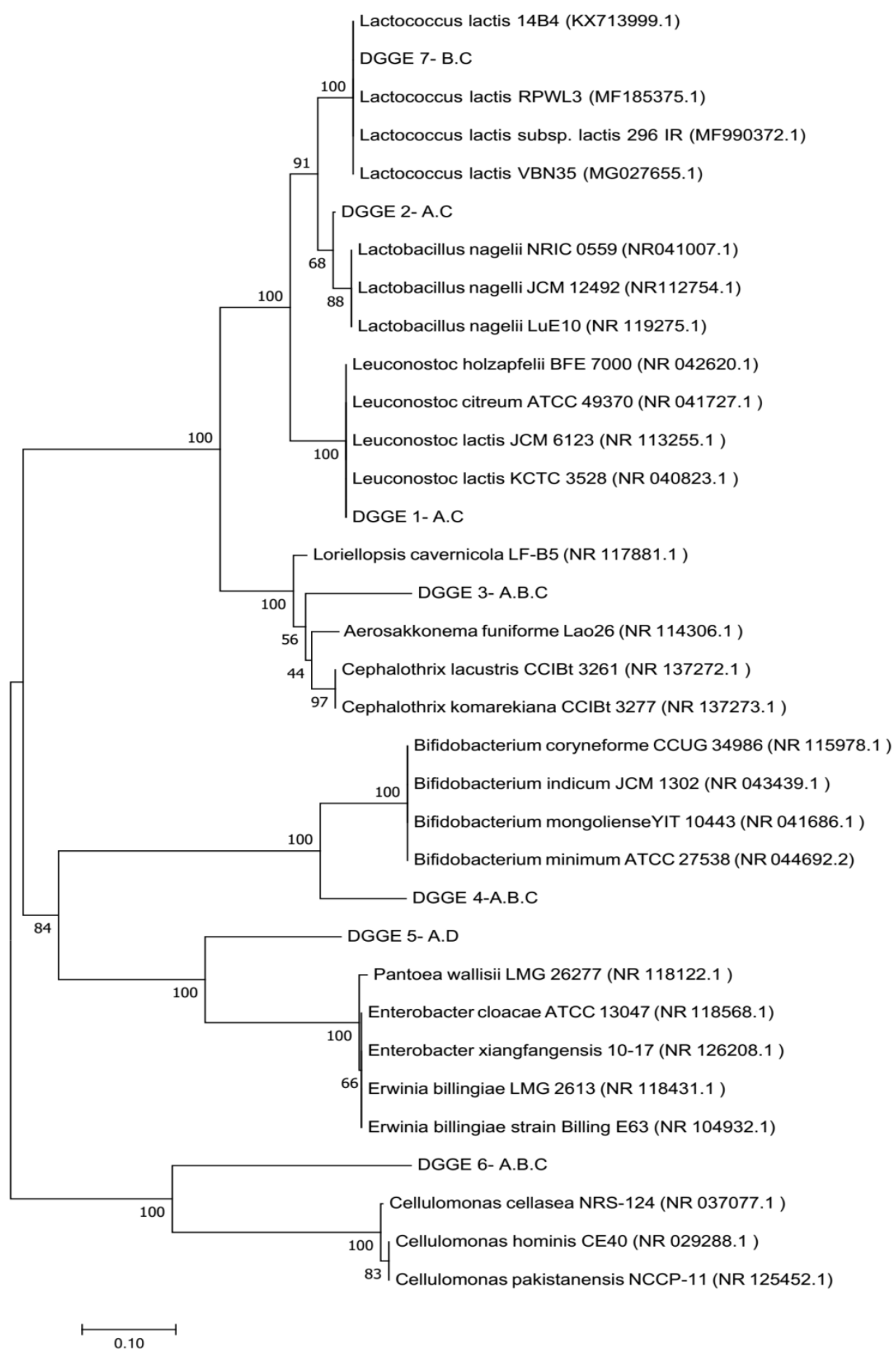

Fig. 2. Phylogenetic tree based of $16 \mathrm{~S}$ rRNA genes sequences of Red Palm Weevil gut bacterial phylotypes in relation to the most closest matches from NCBI GeneBank database. The tree was constructed by using the Neighbor-Joining method. The percentage of replicate trees in which the associated taxa clustered together in the bootstrap test (1000 replicates) are shown next to the branches as percentage. The evolutionary distances were computed using the $p$-distance method. The analysis involved 34 nucleotide sequences. All positions containing gaps and missing data were eliminated. Evolutionary analyses were conducted in MEGA7 
important organic compounds such as, organic acid derivatives, diacetyl, ethyl esters, acetoin, which serve as aggregation pheromones and playing a role in the attraction of other insects and inducing new ovi-position events on the same palm (Guarino et al 2011).

In our investigation Cellulomonas cellasea was identified as a member of red palm weevil gut bacterial community. Genus cellulomonas was detected in gut bacterial community investigations of other coleoptrains; Dendroctonus valens (Coleoptera: Curculionidae) (Morales-Jiménez et al 2009), Oryctes agamemnon (Coleoptera: Scarabaeidae) (El-Sayed and Ibrahim 2015), Anthonomus grandis (Coleoptera: Curculionidae) (Guerrero et al 2016). Genera cellulomonas members are a well-known producers of cellulolytic enzymes, with the ability of degrading cellulose aerobically as well as anaerobically (facultative anaerobes) (Stackebrandt et al 2006), but the presence of cellulolytic bacteria does not prove that the process is actually occurs in the insect gut, especially when we consider the potential impact of the low pHof the red palm weevil gut lumen (Darvishzadeh et al 2012). This impact is supported by the observation of the susceptibility of cellulolytic ruminal bacteria to the low $\mathrm{pH}$ in bovine rumen, as they lose their ability to metabolize cellobiose at low $\mathrm{pH}$ (Russell and Wilson 1996). The relatively low diversity and the presence of a prevailing sugar fermenting bacteria (LAB) make a suggestion that the red palm weevil larva does not depend on the digestion of cellulose as a primary nutrition function, and this hypothesis supported by the fact that, insects that relay on its nutrition on complex substrates; cellulose and hemicellulose-derived materials, tend to select complex gut bacterial communities (Colman et al 2012).

Bifidobacterium minimum is another phylotype which was identified as a common bacterial member. Bifidobacteria generally are anaerobic gram positive bacteria. Few species of this genus are oxygen tolerant, Bifidobacterium minimum is one of the high oxygen tolerant species (Simpson et al 2005), it is also a lactic acid and acetic acid producers (Biavati et al 2000). Bifids are probiotics that are known as commensals in mammalians gut and they were detected previously in gut microbiomic surveys of social insects; honey bees, bumble bees and wasps (Jeyaprakash et al 2003; Mrazek et al 2008; Killer et al 2010 and Kopečný et al 2010), where they are considered to contribute to host's metabolism, physiology and immuno- modulation (Ouwehand et al 2002; Fanning et al 2012).

Pantoea inhabit in various ecosystems such as soil, plant, animals, water and insects, it was detected by (Wang and Zhang, 2015) in association with the larvae gut of mealworm beetle; Tenebrio molitor (Coleoptera: Tenebrionidae). Investigations demonstrated the involvement of pantoea in producing volatiles and antimicrobial phenols which serve as components of aggregation pheromones and chemical antimicrobial barrier to gut infection in Schistocerca gregaria, (Dillon \& Charnley, 1995 and Dillon et al 2002)

In spite of detecting cyanobacteria in red palm weevil gut is considered rather obscure, cyanobacteria were previously detected in wood-feeding huhu beetle larvae; (Prionoplus reticularis) as in active gut flora (Reid et al 2011).

\section{REFERENCES}

Avand, F.A. 1996. The biology of red palm weevil, Rhynchophorus ferrugineus Oliv.(Coleoptera: Curculionidae) in Saravan region (Sistan and Balouchistan Province, Iran). Applied Entomology and Phytopathology, 63, 16-18.

Behar, A., Yuval, B. and Jurkevitch, E. 2008. Gut bacterial communities in the Mediterranean fruit fly (Ceratitis capitata) and their impact on host longevity. J. of Insect Physiology, 54(9), 1377-1383.

Biavati, B., Vescovo, M., Torriani, S. and Bottazzi, V. 2000. Bifidobacteria: history, ecology, physiology and applications. Annals of Microbiology, 50(2), 117-132.

Broderick, N., Goodman, R., Handelsman, J. and Raffa, K. 2003. Effect of host diet and insect source on synergy of gypsy moth (Lepidoptera: Lymantriidae) mortality to Bacillus thuringiensis subsp. kurstaki by zwittermicin A. Environmental entomology, 32(2), 387-391.

Byers, J.A. 1995. Host-tree chemistry affecting colonization in bark beetles. Chemical ecology of insects 2. pp. 154-213, Springer US.

Colman, D.R., Toolson, E.C. and TakacsVesbach, C. 2012. Do diet and taxonomy influence insect gut bacterial communities? Molecular Ecology, 21(20), 5124-5137.

Darvishzadeh, A., Bandani, A.R., Karimi, J. and Timouri, G. 2012. Biochemical characterisation of digestive $\alpha$-amylase of Red Palm Weevil, Rhynchophorus ferrugineus 
(Olivier, 1790) (Coleoptera: Curculionidae). Archives of Phytopathology and Plant Protection, 45(18), 2132-2142.

De Vuyst, L. and Vandamme, E.J. 1994. Antimicrobial potential of lactic acid bacteria. Bacteriocins of lactic acid bacteria. pp. 91-142. Springer US.

DeLong, E.F. and Pace, N.R. 2001. Environmental diversity of bacteria and archaea. Systematic biology, 50(4), 470-478.

Dembilio, Ó. and Jacas, J. 2011. Basic bioecological parameters of the invasive Red Palm Weevil, Rhynchophorus ferrugineus (Coleoptera: Curculionidae), in Phoenix canariensis under Mediterranean climate. Bulletin of Entomological Research, 101(2), 153-163.

Dillon, R. and Charnley, A. 1995. Chemical barriers to gut infection in the desert locust: in vivo production of antimicrobial phenols associated with the bacterium Pantoea agglomerans. J. of Invertebrate Pathology, 66(1), 72-75.

Dillon, R., Vennard, C. and Charnley, A. 2002. A note: gut bacteria produce components of a locust cohesion pheromone. J. of Applied Microbiology, 92(4), 759-763.

El-Sayed, W.S. and Ibrahim, R.A. 2015. Diversity and phylogenetic analysis of endosymbiotic bacteria of the date palm root borer Oryctes agamemnon (Coleoptera: Scarabaeidae). BMC Microbiology, 15(1), 88-97.

Elsaied, H., Kimura, H. and Naganuma, T. 2002. Molecular characterization and endosymbiotic localization of the gene encoding D-ribulose 1, 5-bisphosphate carboxylase-oxygenase (RuBisCO) form II in the deep-sea vestimentiferan trophosome. Microbiology, 148(6), 1947-1957.

Engel, P. and Moran, N.A. 2013. The gut microbiota of insects-diversity in structure and function. FEMS Microbiology Reviews, 37(5), 699-735.

Evans, J.D. and Lopez, D.L. 2004. Bacterial probiotics induce an immune response in the honey bee (Hymenoptera: Apidae). J. of Economic Entomology, 97(3), 752-756.

Fanning, S., Hall, L.J., Cronin, M., Zomer, A., MacSharry, J., Goulding, D. and Dougan, G. $2012 . \quad$ Bifidobacterial surfaceexopolysaccharide facilitates commensal-host interaction through immune modulation and pathogen protection. Proceedings of the National Academy of Sci., 109(6), 2108-2113.
FAOSTAT 2013. Food and Agriculture Organization of the United Nations. FAOSTAT. FAOSTAT (Database). http: //www.fao.org/faostat/en/\#rankings/countries_b y_commodity

Ferry, M. and Gomez, S. 2002. The red palm weevil in the Mediterranean area. PALMSLAWRENCE-, 46, 172-178.

Guarino, S., Bue, P.L., Peri, E. and Colazza, S. 2011. Responses of Rhynchophorus ferrugineus adults to selected synthetic palm esters: electroantennographic studies and trap catches in an urban environment. Pest Management Sci., 67(1), 77-78.

Guerrero, E.B., Soria, M., Salvador, R., CejaNavarro, J.A., Campos, E., Brodie, E.L. and Talia, P. 2016. Effect of Different Lignocellulosic Diets on Bacterial Microbiota and Hydrolytic Enzyme Activities in the Gut of the Cotton Boll Weevil (Anthonomus grandis). Frontiers in Microbiology, 7, 2093-2105.

Hamdi, C., Balloi, A., Essanaa, J., Crotti, E., Gonella, E., Raddadi, N. and Manino, A. 2011. Gut microbiome dysbiosis and honeybee health. J. of Applied Entomology, 135(7), 524-533.

Jeyaprakash, A., Hoy, M.A. and Allsopp, M.H. 2003. Bacterial diversity in worker adults of Apis mellifera capensis and Apis mellifera scutellata (Insecta: Hymenoptera) assessed using $16 \mathrm{~S}$ rRNA sequences. J. of Invertebrate Pathology, 84(2), 96-103.

Killer, J., Kopečný, J., Mrázek, J., Rada, V., Dubná, S. and Marounek, M. 2010. Bifidobacteria in the digestive tract of bumblebees. Anaerobe, 16(2), 165-170.

König, H. and Fröhlich, J. 2009. Lactic acid bacteria. Biology of Microorganisms on Grapes, in Must and in Wine, pp. 3-29, Springer US.

Kopečný, J., Mrázek, J. and Killer, J. 2010. The presence of bifidobacteria in social insects, fish and reptiles. Folia Microbiologica, 55(4), 336339.

Mazza, G., Arizza, V., Baracchi, D., Barzanti, G.P., Benvenuti, C., Francardi, V. and Manachini, B. 2011. Antimicrobial activity of the red palm weevil Rhynchophorus ferrugineus. Bulletin of Insectology, 64(1), 33-41.

Morales-Jiménez, J., Zúñiga, G., Villa-Tanaca, L. and Hernández-Rodríguez, C. 2009. Bacterial community and nitrogen fixation in the red turpentine beetle, Dendroctonus valens LeConte (Coleoptera: Curculionidae: 
Molecular analysis of gut bacterial endosymbionts diversity in Red Palm Weevil larvae,

Rhynchophorus ferrugineus (Coleoptera; Curculionidae)

Scolytinae). Microbial Ecology, 58(4), 879891.

Morewood, W., Hoover, K., Neiner, P., McNeil, J. and Sellmer, J. 2004. Host tree resistance against the polyphagous wood-boring beetle Anoplophora glabripennis. Entomologia Experimentalis et Applicata, 110(1), 79-86.

Mrazek, J., Štrosová, L., Fliegerova, K., Kott, T. and Kopečný, J. 2008. Diversity of insect intestinal microflora. Folia Microbiologica, 53(3), 229-233.

Murphy, S. and Briscoe, B. 1999. The red palm weevil as an alien invasive: biology and the prospects for biological control as a component of IPM. Biocontrol News and Information, 20, 35-46.

Muyzer, G., De Waal, E.C. and Uitterlinden, A.G. 1993. Profiling of complex microbial populations by denaturing gradient gel electrophoresis analysis of polymerase chain reaction-amplified genes coding for $16 \mathrm{~S}$ rRNA. Applied and Environmental Microbiology, 59(3), 695-700.

Muyzer, G. and Smalla, K. 1998. Application of denaturing gradient gel electrophoresis (DGGE) and temperature gradient gel electrophoresis (TGGE) in microbial ecology. Antonie van Leeuwenhoek, 73(1), 127-141.

Oliver, K.M., Degnan, P.H., Burke, G.R. and Moran, N.A. 2010. Facultative symbionts in aphids and the horizontal transfer of ecologically important traits. Annual Review of Entomology, 55, 247-266.

Ouwehand, A.C., Salminen, S. and Isolauri, E. 2002. Probiotics: an overview of beneficial effects Lactic Acid Bacteria: Genetics, Metabolism and Applications, pp. 279-289, Springer US.

Rajamanickam, K., Christopher, A. and Kennedy, J. 1995. Certain components of integrated management for red palm weevil, Rhynchophorus ferrugineus .(Curculionidae: Coleoptera) on coconut [in South India]. Mededelingen Faculteit Landbouwkundige en Toegepaste Biologische Wetenschappen, 60, 803-805.

Reid, N.M., Addison, S.L., Macdonald, L.J. and Lloyd-Jones, G. 2011. Biodiversity of active and inactive bacteria in the gut flora of woodfeeding huhu beetle larvae (Prionoplus reticularis). Applied and Environmental Microbiology, 77(19), 7000-7006.

Russell, J.B. and Wilson, D.B. 1996. Why are ruminal cellulolytic bacteria unable to digest cellulose at low $\mathrm{pH}$ ?. J. of dairy Sci., 79(8),1503-1509.

Ryu, J.H., Kim, S.H., Lee, H.Y., Bai, J.Y., Nam, Y.D., Bae, J.W. and Lee, W.J. 2008. Innate immune homeostasis by the homeobox gene caudal and commensal-gut mutualism in Drosophila. Science, 319, 777-782.

Simpson, P., Stanton, C., Fitzgerald, G. and Ross, R. 2005. Intrinsic tolerance of Bifidobacterium species to heat and oxygen and survival following spray drying and storage. J. of Applied Microbiology, 99(3), 493-501.

Stackebrandt, E., Schumann, P. and Prauser, H. 2006. The family Cellulomonadaceae. The prokaryotes pp. 983-1001, Springer US.

Vandenbergh, P.A. 1993. Lactic acid bacteria, their metabolic products and interference with microbial growth. FEMS Microbiology Reviews, 12(3), 221-237.

Verstraete, W., Wittebolle, L., Heylen, K., Vanparys, B., De Vos, P., Van de Wiele, T. and Boon, N. 2007. Microbial resource management: the road to go for environmental biotechnology. Engineering in Life Sci., 7(2), 117-126.

Wang, Y. and Zhang, Y. 2015. Investigation of gut-associated bacteria in Tenebrio molitor (Coleoptera: Tenebrionidae) larvae using culture-dependent and DGGE methods. Annals of the Entomological Society of America, 108(5), 941-949.

War, A.R., Paulraj, M.G., Ahmad, T., Buhroo, A. A., Hussain, B., Ignacimuthu, S. and Sharma, H.C. 2012. Mechanisms of plant defense against insect herbivores. Plant Signaling \& Behavior, 7(10), 1306-1320.

Zouine, J., El-Bellaj, M., Meddich, A., Verdeil, J.L. and El-Hadrami, I. 2005. Proliferation and germination of somatic embryos from embryogenic suspension cultures in Phoenix dactylifera. Plant Cell, Tissue and Organ Culture, 82(1), 83-92. 